\author{
DEPARTMENT OF THE INTERIOR \\ UNITED STATES GEOLOGICAL SURVEY
}

A CONTRIBUTION OF THE NATIONAL CENTER

FOR EARTHQUAKE RESEARCH

\title{
MAP SHOWING RECENTLY ACTIVE BREAKS ALONG THE SAN ANDREAS AND RELATED FAULTS BETWEEN CHOLAME VALLEY AND TEJON PASS, CALIFORNIA By
}

J. G. Vedder and Robert E. Wallace

\author{
MISCELLANEOUS GEOLOGIC INVESTIGATIONS \\ MAP I-574
}

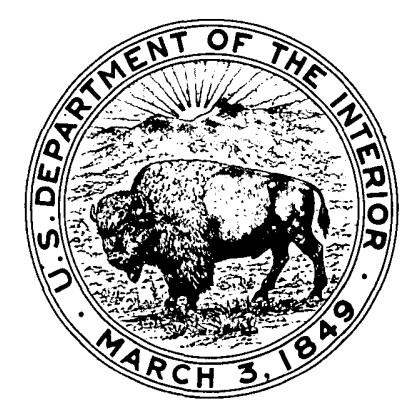

PUBLISHED BY THE U.S. GEOLOGICAL SURVEY WASHINGTON. D. C. 